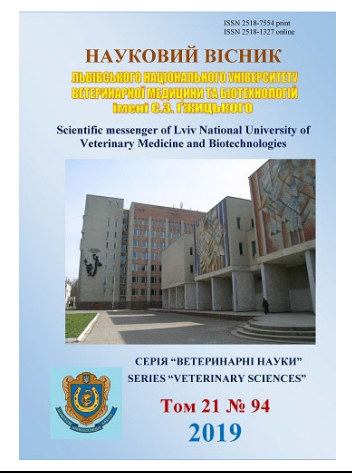

\author{
Науковий вісник Дьвівського національного університету \\ ветеринарної медицини та біотехнологій імені С.3. Гжицького. \\ Серія: Ветеринарні науки \\ Scientific Messenger of Lviv National University \\ of Veterinary Medicine and Biotechnologies. \\ Series: Veterinary sciences
}

\title{
The effectiveness of the treatment of cows with mastitis
}

\author{
D.B. Zainettinova ${ }^{1}$, N.N. Muhamadieva ${ }^{1}$, M.N. Julanov $^{2}$, V.Yu. Stefanyk ${ }^{3}$, V.V. Zaviruha ${ }^{3}$, I.A. Sarhambaeva ${ }^{1}$ \\ ${ }^{1}$ Shakarim State University of Semey, Kazakhstan \\ ${ }^{2}$ Kazakh National Agrarian University, Almaty, Kazakhstan \\ ${ }^{2}$ Stepan Gzhytskyi National University of Veterinary Medicine and Biotechnologies Lviv, Ukraine
}

Article info

Received 08.04.2019

Received in revised form 08.05.2019

Accepted 09.05.2019

Shakarim State University of Semey, 070000, Kazakhstan.

Kazakh National Agrarian University, Almaty, 050000 , Kazakhstan.

E-mail:tnt_rani@mail.ru

Stepan Gzhytskyi National University of Veterinary Medicine and Biotechnologies Lviv, Pekarska Str., 50, Lviv, 79010, Ukraine. Tel. $+38-050-663-52-12$ E-mail: stefanyk@bigmir.net

Zainettinova, D.B., Muhamadieva, N.N., Julanov, M.N., Stefanyk, V.Yu., Zaviruha, V.I., \& Sarhambaeva, I.A. (2019). The effectiveness of the treatment of cows with mastitis. Scientific Messenger of Lviv National University of Veterinary Medicine and Biotechnologies. Series: Veterinary sciences, 21(94), 78-81. doi: 10.32718/nvlvet9414

The main sector of agriculture in Kazakhstan, including the East Kazakhstan region is cattle breeding and, in particular, cattle breeding, which is determined by climatic and geographical conditions. However, successful reproduction and increase in livestock productivity is largely hampered by infertility and mastitis, and as a result they cause significant economic damage and reduce the reproduction rate and profitability of dairy cattle. Recently, the number of subclinical mastitis in cows has increased, which subsequently lead to profound morphological and functional changes in the mammary gland, a decrease in milk productivity and quality. Mastitis can be caused by various reasons, primarily poor or inadequate feeding, poor care, improper maintenance and use of animals, negligent attitudes towards organizing and conducting artificial insemination, due to various diseases of the genital organs, which appear most often during childbirth and the postpartum period. The quality control of the milk of cows was investigated by California test and DEDM (Device for Express Diagnostic of Mastitis). The express methods that we used allowed us to identify the subclinical and clinical forms of mastitis and timely treat it. Laboratory studies on the presence of somatic cells in milk were also conducted. After the detection of breast diseases, complex symptomatic treatment was performed. For the treatment of various forms of mastitis, drugs were used: mastiet forte intracisternally for five days at a dose of $10 \mathrm{ml} 2$ times a day for five days in a row. Mastiet Forte has a high therapeutic efficacy in subclinical and clinical forms of cow mastitis. And the drug ketoprof has also been used. Ketoprof as an anti-inflammatory agent was used intramuscularly - $3 \mathrm{ml} \mathrm{per} 100 \mathrm{~kg}$ of animal weight 1 time per day for 3 days in a row. Klineksin 5\%, as an antibacterial agent, was used intramuscularly at a dose of $1 \mathrm{ml}$ per $50 \mathrm{~kg}$ of body weight 1 time per day for 3 days in a row. Antimicrobial agents and biologically active substances needed to be combined for successful therapy. Such biologically active substances include vitamin of Helsivit. They were used subcutaneously - $6 \mathrm{ml}$ once.

Key words: mastitis, milk, udder, diagnostics, California test, Mastiet forte, ketoprof, klineksin 5\%, vitamin of helsivit, Laktan1-4M.

\section{Introduction}

One of the most valuable food is milk. The main way to increase its production is the creation of healthy, highly productive herds. The concentration of livestock on large farms and complexes, the mechanization of basic production processes, including milking, revealed to the specialists a number of serious problems for the prevention of serious diseases. A special place in them are breast diseases, which significantly affect the productivity of animals, reduce the quality of milk.
Getting a high-quality and safe cow milk is an actual task for dairy farms (Vasiliev, 2012; Verkholomov, 2012; Larionov et al., 2012; Shepeleva, 2012; Rodionov et al., 2012; Rodionov, et al., 2013; Chikina, 2013).

The genetic potential of the livestock of cattle herds, the quantity, balance and safety of the feed, housing conditions, milking technology and cow care have a complex effect on milk production and milk quality (Schukken et al., 1993; Zhelavskyi, 2018).

Mastitis of cows causes significant damage to farms due to reduced milk quality and productivity of cows, 
treatment costs, premature culling of cows (Hulps et al., 2010; Bagmanov, 2011; Kolchina et al., 2012).

According to foreign studies, subclinical mastitis is recorded in $90 \%$ of cases, whereas clinically significant inflammation occurs only in 3-10\% (Bekken \& Thorburn, 1985).

In the milk of cows with mastitis, there are significant physical and chemical changes, as a result of which it becomes a low-value food product and loses its technological properties during industrial processing. In addition, mammary gland inflammation leads to hypogalactia and, in some cases, to complete atrophy of the affected quarter of the udder. With subclinical mastitis, one udder lobe from each sick cow loses on average up to $10-15 \%$ of milk per lactation. Therefore, it is necessary to introduce into the milk production technology a complex of effective preventive measures to fight breast diseases in cows, in particular, mastitis (Krukowski, 2000; Malinowski, 2004).

For successful treatment of mastitis of cows, it is necessary to combine antimicrobial agents and biologically active substances. Such biologically active substances include vitamins, enzymes, hormones and micro elements, yeast, probiotics. These substances contribute to the normalization of metabolism in animals, activate the system of natural resistance, and thereby contribute to the effectiveness of anti-mastitis therapy (Parikov, 1990).

Until recently, the main treatment for mastitis was antibacterial therapy. The effectiveness of the use of antibiotics depends on many factors, but the determining factor is the specific features of interaction of the antibiotic directly with the pathogen. The processes of interaction between the antibacterial agent and the antibiotic are determined by the pharmacokinetic characteristics of the drug, the sensitivity of the microorganism to it, and the ability of the bacteria to "defend" (develop resistance). The development of antimicrobial resistance in many bacterial pathogens makes the treatment with traditional anti-mastitis drugs ineffective, which makes the veterinarian to "pick up" a more effective remedy by successively changing the group of antibiotics or a combination of different drugs.However, such approach often cannot be acceptable, since in acute clinical mastitis a quick and pronounced effect is required (Oleinik, 2008).

Also, one of the causes of this pathology may be the uncontrolled use of antibiotics, which in turn causes the formation of antibiotic-resistant microorganisms, leading to the occurrence of the disease (Atheer et al., 2018).

The main method of preventing diseases of the udder is a scientifically-based, cost-effective management of livestock while observing zoohygienic standards of housing, feeding and milking, which provide a high level of natural resistance of the body and animal productivity.

The aim of this work was to study the therapeutic efficacy of applying the method of treating cows with subclinical and clinical mastitis.

\section{Materials and methods}

The cows of the farms of "Balke", "Kalikhanuly" and "Madi-R" served as the material, where we conducted a study on subclinical and clinical forms of mastitis.

120 dairy cows of the black-and- motley breed at the age of 5-6 years with a body weight of 450-500 kg were used for research.

The diagnosis was established on the basis of the collection of anamnesis of clinical and laboratory research results.

The quality control of the milk of cows was investigated by the California test and DEDM (Device for Express Diagnostic of Mastitis).

The express methods that we used allowed us to identify the subclinical and clinical forms of mastitis and timely treat it. Laboratory studies on the presence of somatic cells in milk were also conducted.

After the detection of mammary gland diseases, complex symptomatic treatment was performed.

\section{Results and discussion}

During the study of 120 cows, $53.3 \%$ of cases of subclinical form of mastitis were detected, and the clinical forms of mastitis were $12.4 \%$.

In addition, laboratory tests were conducted for the presence of somatic cells in milk by the Laktan1-4 M apparatus and the California test. So, at the beginning of the experience, their number was determined within 590 thousand - 620 thousand, which is typical for subclinical mastitis. The data obtained as a result of the research are presented in table 1 .

\section{Table 1}

Number of cows with mastitis

\begin{tabular}{lccc}
\hline \multicolumn{1}{c}{ Types of mastitis } & Total number of cows & Number of sick cows & Sickness indicator (\%) \\
\hline Subclinical Mastitis & & 64 & $53,3 \%$ \\
Catarral & 120 & 8 & $6,6 \%$ \\
Purulent-catarrhal & & 7 & $5,8 \%$ \\
\hline
\end{tabular}

In order to determine the therapeutic efficacy of the drug, 64 cows, sick with subclinical mastitis, 8-catarrhal, 7-purulent-catarrhal mastitis were selected from three farms during the year.

For treatment, two schemes were used. For cows with catarrhal and purulent-catarrhal mastitis in the first scheme, Mastiet forte, ketoprof and vitamin of Khelsivit were used. And cows with subclinical mastitis were treated with mastitis forte and clinex $5 \%$, with vitamin of Helsivit. 
Table 2

A scheme of treatment of mastitis No. 1

\begin{tabular}{|c|c|c|c|c|c|c|c|}
\hline \multirow{2}{*}{ Name of the drug } & \multirow{2}{*}{ Use } & \multirow{2}{*}{ Dose } & \multicolumn{5}{|c|}{ Days of treatment } \\
\hline & & & 1 & 2 & 3 & 4 & 5 \\
\hline Mastiet Forte & intracisternally & 1 syringe dispenser & ++ & ++ & ++ & ++ & ++ \\
\hline Ketoprof & intramuscularly & $3 \mathrm{ml}$ per $100 \mathrm{~kg}$ & + & + & + & & \\
\hline Vitamin of Helsivit & intramuscularly & $6 \mathrm{ml}$ & + & & & & \\
\hline
\end{tabular}

Table 3

A scheme of treatment of mastitis No. 2

\begin{tabular}{|c|c|c|c|c|c|c|c|}
\hline \multirow{2}{*}{ Name of the drug } & \multirow{2}{*}{ Use } & \multirow{2}{*}{ Dose } & \multicolumn{5}{|c|}{ Days of treatment } \\
\hline & & & 1 & 2 & 3 & 4 & 5 \\
\hline Mastiet Forte & intracisternally & 1 syringe dispenser & ++ & ++ & ++ & ++ & ++ \\
\hline Klineksin 5\% & intramuscularly & $1 \mathrm{ml}$ per $50 \mathrm{~kg}$ & + & + & + & & \\
\hline Vitamin of Helsivit & intramuscularly & $6 \mathrm{ml}$ & + & & & & \\
\hline
\end{tabular}

Mastiet forte was used intracisternally for five days at a dose of $10 \mathrm{ml} 2$ times a day for five days in a row. Mastiet Forte has a high therapeutic efficacy in subclinical and clinical forms of cow mastitis. After the drug was injected, a light massage of the affected quarter of the udder was performed to evenly distribute the drug in the lobe. And the drug ketoprof was also used. Ketoprof as an anti-inflammatory agent was used intramuscularly $-3 \mathrm{ml}$ per $100 \mathrm{~kg}$ of animal weight 1 time per day for 3 days in a row. Klineksin 5\%, as an antibacterial agent, was used intramuscularly at a dose of $1 \mathrm{ml}$ per $50 \mathrm{~kg}$ of body weight 1 time per day for 3 days in a row. Antimicrobial agents and biologically active substances needed to be combined for successful therapy. Such biologically active substances include vitamin of Helsivit. Helsivit was used subcutaneously $-6 \mathrm{ml}$ once.

Laboratory studies conducted in the apparatus "Laktan 1-4M" for the presence of somatic cells in milk 3 days after the first treatment scheme were within 480 thousand, and in the second treatment scheme were 490 thousand somatic cells.

After five days after the last use of drugs, the results of the treatment were evaluated. The recovery of cows with subclinical and clinical forms of mastitis was again determined and the milk of all quarters of the udder was examined after 3-5 days by DEDM (Device for Express Diagnostic of Mastitis) and the California test. The cows were considered recovered if the milk sample showed a

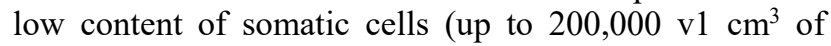
milk), there were no changes in the secret.

The effectiveness of the treatment of the first scheme was $93 \%$, and in the second scheme was $95 \%$.

Thus, our research and complex treatment gave a very good result, not only in the treatment of these cows, but also prophylactic efficacy in the conducted research of the farms.

Therefore, the study of specific causes contributing to the occurrence of these diseases, their diagnosis, treatment and prevention are of great practical importance.

\section{Conclusions}

Drugs of the first and second schemes have a high therapeutic activity, which has reduced the time of treatment of subclinical and clinical mastitis, as well as the timing of culling milk. In both cases of the use of mastiet forte, there was not noted its negative effect on the general condition of the animals, local irritant or sensitizing effect of the drug. With the introduction of the drug in dairy tanks, the active ingredients penetrate the udder parenchyma, remaining in therapeutic concentrations for 12 hours.

\section{References}

Vasiliev, R. (2012). Food Safety Management. Dairy Industry, 10, 51.

Verkholomov, E. (2012). How to improve the grade of milk. Animal Husbandry of Russia, 6, 64 .

Larionov, G.A., Shchiptsova, N.V., \& Milovidova, N.I. (2012). Assessment of the quality of milk in the Chuvash Republic. Problems of veterinary sanitation, hygiene and ecology. M.: GNU VNIIVSGE RAASHN, 2(8), 9-11.

Shepeleva, E. (2012). Principles of HACCP: international standards in the field of food safety management. Dairy industry, 9, 62 .

Rodionov, G.V., \& Ananyeva, T.V., \& Kuzhuget, E. (2012). Regulation of the content of microorganisms in raw milk. Dairy industry, 8, 14-15.

Rodionov, G.V., Belopukhov, S.L., Mannapova, R.T., \& Dryakhlykh, O.G. (2013). Regulation of the number of microorganisms in raw milk. News of the Timiryazev Agricultural Academy, 1, 111-119.

Chikina L.V. (2013). Inspection of the quality and safety of milk and dairy products. Dairy industry, 1, 20-21.

Schukken, Y.H., Weersink, A., Leslie, K.E., \& Martin, S.W. (1993). Dynamics and Regulation of Bulk Milk Somatic Cell Counts. Can. J. Vet. Res., 57(2), 131-135. https://www.ncbi.nlm.nih.gov/pmc/articles/PMC126360 7.

Zhelavskyi, M.M. (2018). Changes in the immunobiological reactivity of the organism of cows 
in the pathogenesis of mastitis. Scientific Messenger of Lviv National University of Veterinary Medicine and Biotechnologies. 20(83), 77-82. doi: $10.15421 /$ nvlvet8315.

Bagmanov, M.A. (2011). Breast pathology in domestic animals. Monograph. Kazan.

Hulps, K., Lam, T.J., \& Hogeveen, H. (2010). Costs of mastitis: facts and perception. S. Dairy Res., 75(1), 113-120. doi: 10.1017/S0022029907002932.

Kolchina, A.F., Barkova, A.S., \& Barashkin, M.I. (2012). Modern methods in diagnosing the pathology of the mammary gland of highly productive cows. Agrarian Bulletin of the Urals, 12(104), 12-14.

Bekken, G., \& Thorburn, M. (1985). Beriousness and stability of Subclinical mastitis assessed by the quarter milk serum albumin. Acta Veter. Scand., 2(2), 275285.

Krukowski, H. (2000). Zapalenia wymienia na tle grzybiczym u krow. Medycyna Wet., 57, 18-20.

Malinowski, E. (2004). Mastitis u krow. Pulawy, 50.

Parikov, V.A. (1990). Development and improvement of methods for the diagnosis, treatment and prevention of mastitis in cows. Dissertation in the form of scientific report on the Doctor of Veterinary Science. Voronezh.

Oleinik, A.V. (2008). Kobantan LC for mastitis in cows. Veterinary, 2, 18.

Atheer, A.R., Ansam, K.M., Nuhad, M.H., Kifah, A.J., Zaid, S.A., \& Harith, J.F.A. (2018). Gentamicin enhances mastitis toxA expression in Pseudomonas aeruginosa. Adv. Anim. Vet. Sci., 6(12), 526-530. doi: 10.17582/journal.aavs/2018/6.12.526.530. 